\title{
Caracterização dos Produtos Desenvolvidos por um Programa de Mestrado Profissional da Área de Ensino de Ciências e Tecnologia
}

\author{
Tania Mara Niezer \\ Fabiane Fabri \\ Antonio Carlos Frasson
}

Luiz Alberto Pilatti

\begin{abstract}
Resumo
Este trabalho tem por objetivo mapear os produtos finais obtidos a partir de dissertações geradas no Mestrado Profissional (MP) do programa de PósGraduação em Ensino de Ciência e Tecnologia (PPGECT) da Universidade Tecnológica Federal do Paraná - Câmpus Ponta Grossa (UTFPR) na Área de Ensino de Ciências e Tecnologia defendidas no período de 2009 a 2013. Trata-se de um estudo descritivo. Foram identificados os produtos disponibilizados no site do PPGECT para a construção do corpus documental. Os produtos foram classificados buscando caracterizar sua área de ensino, a amostra da população e o formato dos materiais finais. O público atendido foram os alunos do programa (PPGECT) que vão desde professores da educação básica até o ensino superior. Foram identificados 68 produtos, predominando o formato Guias Didáticos e abrangência na área de ensino de Matemática voltado ao Ensino Fundamental. Os resultados demonstraram que a maioria dos produtos finais se constitui, em sua essência, em Guias Didáticos, sendo a área de maior abrangência a do ensino de Matemática e desenvolvidos no Ensino Fundamental.
\end{abstract}

Palavras-chave: Mestrado Profissional, Produto Educacional, Ensino de Ciências.

\section{Abstract \\ Characterization of Products Developed by a Professional Master's Program Area of Teaching Science and Technology}

This work aims at mapping the final products obtained from dissertations generated in Master Professional (MP) of the Graduate Program in Teaching Science and Technology (PPGECT) of the Federal Technological University of Paraná - Campus Ponta Grossa (UTFPR) in area of Science Education and Technology defended the period 2009 to 2013 This is a descriptive study. Products made available on the site for the construction PPGECT documentary corpus were identified. Products classified seeking to characterize their teaching, the sample population and the format of the final materials. 68 products were identified, predominantly Guides Instructional format and scope in the area of mathematics teaching geared to elementary school. The results showed that the majority of end products constitutes, in essence, Teaching Guides, being the area of greatest scope to the teaching of Mathematics and developed in Elementary Education.

DOI: Em andamento. 


\section{Introdução}

O Mestrado Profissional (MP) é uma modalidade diferente de formação em nível stricto sensu regulamentado pela Portaria CAPES 80/1998, que prioriza o atendimento aos profissionais de diversos setores que estejam trabalhando na Área de estudo, com o intuito de promover melhor articulação entre universidade e a sociedade.

O MP escolhido para desenvolver este estudo abrange a Área de Ensino de Ciências e Tecnologia tendo como público alvo, docentes que atuam nesta área. O Mestrado Profissional (MP) do programa de Pós-Graduação em Ensino de Ciência e Tecnologia (PPGECT) da Universidade Tecnológica Federal do Paraná - Campus Ponta Grossa (UTFPR), com a proposta de integrar o rigor da pesquisa ao seu processo de desenvolvimento, busca consolidar a aplicação dos resultados para transformar a realidade estudada.

Tal programa obteve aprovação da CAPES em julho de 2007, e desde então atenta para a promoção de diálogos inter e multidisciplinares no processo de formação profissional que contribua para a ação reflexiva, crítica e inovadora da atividade docente. O MP em questão considera os estudos e pesquisas realizados no contexto de sala de aula como objeto de investigação, defendendo que a produção de conhecimento está diretamente associada á prospecção de problemas e soluções para o ensino-aprendizagem dos conhecimentos científicotecnológicos.

Com esse enfoque, o objetivo do programa é dar suporte teórico para que o docente tenha condições de inovar sua prática em termos de compreensão e aplicação da ciência e da tecnologia. Compreende-se que a pesquisa, abordada dessa maneira, aproxima os estudos promovidos na Academia às práticas escolares.

Nas palavras de Negret (2009), o desafio, que significa o verdadeiro sentido da universidade, implica a inserção dos MP no âmbito da sociedade para realizar com eficiência e clareza os estudos e análises e, desse modo, alcançar a compreensão dos conflitos e problemas.

Compreende-se assim, que os produtos finais ou educacionais (MOREIRA, NARDI, 2009) como também são chamados, gerados a partir das dissertações dos MP, adquirem caráter prático, de aplicação, voltados para a instrumentalização do ensino em determinado contexto social.

Considerando isso, Latini et al (2011) apontam que os produtos gerados como fruto das pesquisas no MP têm sido objeto de discussão nas Áreas de Ensino de Ciências, porém, ainda não existe um referencial que defina as propriedades destes produtos.

No foco de estudo sobre os produtos finais, este trabalho buscou mapear os diversificados tipos de produções geradas das dissertações de um Mestrado Profissional na Área 
de Ensino de Ciências e Tecnologia, geradas pelo programa de Pós-Graduação em Ensino de Ciência e Tecnologia (PPGECT) da Universidade Tecnológica Federal do Paraná - Câmpus Ponta Grossa (UTFPR) na Área de Ensino de Ciências e Tecnologia defendidas no período de 2009 a 2013.

\section{Mestrado Profissional: oportunidade de formação continuada}

No âmbito educacional, compreende-se que a formação profissional seja fundamental na possibilidade do professor, de desenvolver a capacidade de refletir sobre sua ação pedagógica, promovendo situações de aprendizagem que oportunizem ao aluno pensar criticamente sobre as transformações do mundo. A formação continuada, nesse contexto, sugere a melhoria do processo de ensino, porém, exige do professor disposição para conciliar tempo de estudo e carga horária de trabalho docente.

Atenta-se que o professor da escola básica pode ser concebido como investigador sobre temáticas e problemáticas relativas às práticas de ensinar e aprender, por isso torna-se um pesquisador capaz de utilizar criticamente seu saber acadêmico como instrumento de compreensão, problematização e transformação de sua atividade docente. Tal conexão entre teoria e prática, permite ao professor agir no seu campo de pesquisa, dimensionando a necessidade de um processo de formação continuada que valorize essa possibilidade de intervenção do pesquisador.

Nesse entorno, o Mestrado Profissional foi criado como um programa condizente com a feição peculiar do Mestrado dirigido à formação profissional com padrão da pós-graduação stricto sensu. Amparado pela Portaria $n^{\circ}$ 080, da Capes de 16 de dezembro de 1998, o Mestrado Profissional (MP) tem como premissas:

"(a) necessidade da formação de profissionais pós-graduados aptos a elaborar novas técnicas e processos; (b) a relevância do caráter de terminalidade, ou seja, ênfase no aprofundamento da formação científica ou profissional conquistada na graduação, e (c) manutenção de níveis de qualidade condizentes com os padrões da pós-graduação stricto sensu e consistentes com a feição peculiar do Mestrado dirigido à formação profissional" (CAPES, 1998).

Conforme disposto na Portaria Normativa $N^{\circ} 7$ da Capes, de 22 de junho de 2009, o Art. $4^{\circ}$ atribui como sendo os objetivos do Mestrado Profissional:

"I - capacitar profissionais qualificados para o exercício da prática profissional avançada e transformadora de procedimentos, visando atender demandas sociais, organizacionais ou profissionais e do mercado de trabalho; II transferir conhecimento para a sociedade, atendendo demandas específicas $e$

DOI: Em andamento. 
de arranjos produtivos com vistas ao desenvolvimento nacional, regional ou local; III - promover a articulação integrada da formação profissional com entidades demandantes de naturezas diversas, visando melhorar a eficácia e a eficiência das organizações públicas e privadas por meio da solução de problemas e geração e aplicação de processos de inovação apropriados; IV contribuir para agregar competitividade e aumentar a produtividade em empresas, organizações públicas e privadas".

Com foco na formação continuada, o MP se apresenta relevante a uma determinada área profissional, definindo sua estrutura curricular aos anseios do público alvo e sendo ofertado de forma diferenciada e flexível com propostas de dedicação parcial. Moreira e Nardi (2009) relatam que o público-alvo dos MP é prioritariamente constituído de professores em serviço sendo que as atividades didáticas procuram ser organizadas de forma a viabilizar a participação dos alunos.

Latini et al (2011), declaram que a proposta do MP, "propicia a redução do distanciamento social presente até então na relação entre o sujeito que pesquisa e os que constituem seu objeto de estudo". Os autores consideram ainda que em termos de produção de conhecimento, as pesquisas realizadas no MP têm como característica o fato de serem desenvolvidas a partir de uma perspectiva 'de dentro' do contexto analisado.

Negret (2009) salienta que, a identidade dos mestrados profissionais não está somente determinada pela sua área temática, mas, fundamentalmente, pelo enorme desafio de integrar com rigor a pesquisa no seu processo de desenvolvimento e conseguir a aplicabilidade dos resultados para transformar a realidade estudada.

O MP pode ser entendido, também, como um processo de desenvolvimento de análise de situações com foco na "resolução de problemas que inclui a capacidade de refletir e atuar criticamente sobre seu processo de trabalho" (HORTALE et al, 2010).

O MP na Área de Ensino de Ciências e Tecnologia do PPGECT-UTFPR Campus Ponta Grossa, descreve como objetivos do curso proporcionar qualificação científica e formação profissional nas áreas de ensino, oportunizando formação continuada na área de abrangência do programa, contribuindo para elevar a capacidade de elaborar novas estratégias e processos de entender, questionar e utilizar os conhecimentos científicos e tecnológicos, a fim de contribuir para melhoria do processo de ensino-aprendizagem em seus diversos níveis.

Nesse sentido, considera-se relevante fazer-se uma caracterização do que já se produziu no mestrado em questão e, a partir do extrato dos produtos, ampliar possibilidades de novos encaminhamentos para elaboração de produtos em áreas, disciplinas ou modelos que ainda não tenham sido contemplados. 


\section{Sobre o Produto do Mestrado Profissional}

Outra especificidade do MP que o difere do mestrado acadêmico, diz respeito aos modelos de avaliação e ao produto final a ser desenvolvido com pré requisito de conclusão de curso. Em seu caráter pedagógico, o produto final visa integrar teoria prática, possibilitando a aproximação entre a produção científica e o desenvolvimento de tecnologia e inovação.

Sobre o produto, Fernandes (p. 108, 2005) define como sendo uma exigência da apresentação de um trabalho final do MP "que tenha um caráter predominantemente aplicado, no dia-a-dia do aluno, em seu ambiente profissional, e que pode ser apresentado sob a forma de dissertação, projeto, análise de casos, performance, produção artística,desenvolvimento de instrumentos, equipamentos, protótipos, entre outras, de acordo com a natureza da área e a finalidade do curso".

O trabalho de conclusão do mestrado profissional, de acordo com Moreira e Nardi (2009), trata-se do relato de experiência de implementação de estratégias ou produtos de natureza educacional, que objetivam a melhoria de uma área específica.

Nesse sentido, o produto a ser desenvolvido pelo MP pode ser, por exemplo,

"alguma nova estratégia de ensino, uma nova metodologia de ensino para determinados conteúdos, um aplicativo, um ambiente virtual, um texto; enfim, um processo ou produto de natureza educacional e implementá-lo em condições reais de sala de aula ou de espaços não formais ou informais de ensino, relatando os resultados dessa experiência". (MOREIRA, NARDI, p. 4, 2009).

Dessa forma, esses produtos finais trazem em sua essência o caráter autônomo de pensamento elaborado a partir da pesquisa aplicada com a proposta de compartilhar de experiências e instrumentalizar seus pares. Esse material educacional pode se configurar em forma de aplicativo, sequência didática, DVD, CD, equipamento ou qualquer outro que possa ser disseminado, analisado e utilizado por outros professores (MOREIRA, NARDI, 2009).

Neste estudo, buscamos analisar e caracterizar que tipo de produto foi gerado pelas dissertações no MP na área de Ciência e Tecnologia, relacionando o nível de ensino em que foi aplicado e a área de conhecimento da pesquisa.

\section{Metodologia}

O presente estudo, do ponto de vista dos seus objetivos, classifica-se como descritivo. Com a pesquisa descritiva é possível observar, registrar, analisar e correlacionar as características do fenômeno estudado sem a manipulação da ou das variáveis envolvidas.

DOI: Em andamento. 
Para a construção do corpus documental foram compiladas as informações das dissertações e seus produtos disponibilizados no sítio do PPGECT na rede mundial de computadores. Foram levantados os seguintes dados no material que compõe o corpus: linha de pesquisa, sublinha, o título da dissertação, o nível de ensino e o formato do produto. Tais informações foram organizadas em fichas e, posteriormente, transcritas em tabelas. A seguir apresenta-se um gráfico com o percentual anual das 68 dissertações disponibilizadas no site desde 2009 até 2013.

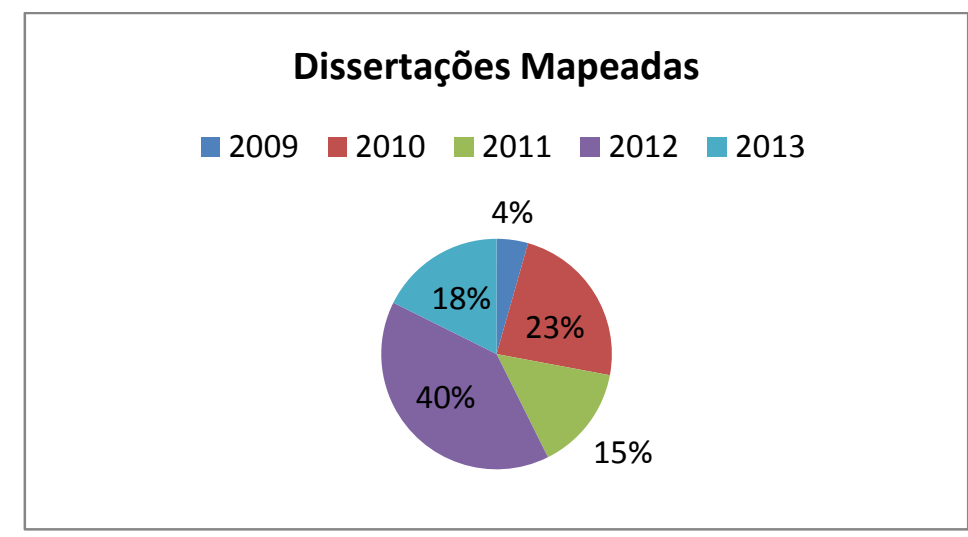

Gráfico 1 - Dissertações produzidas no

Mestrado Profissional em Ensino de Ciência e Tecnologia da UTFPR -

Campus Ponta Grossa

(Fonte: Autoria própria)

No gráfico 1 é possível perceber que o número de dissertações disponibilizadas no site do referido programa (http://ppgect.pg.utfpr.edu.br/site/?page_id=344) foi maior no ano de 2012. Uma explicação para essa ocorrência está na relação de egressos durante os anos, que possivelmente, aumentou a atualização do site do programa com a alimentação dos materiais defendidos além das prorrogações que acabam sendo feitas pelos alunos devido a vários motivos: como motivos pessoais, tratamento de saúde, tempo insuficiente e o exame de suficiência em inglês, pois todos os egressos precisam apresentar esse exame ao término do curso de mestrado ${ }^{1}$.

Conforme informações obtidas, os quadros apresentados na sequência demonstram a relação das categorias de análise: linha, sublinha, título, nível de ensino e formato do produto, referentes a cada ano de publicação.

No foco do MP da PPGECT, as pesquisas desenvolvidas abrangem a área: Ciência, Tecnologia e Ensino e duas linhas de pesquisa: Fundamentos e metodologias para o ensino de

${ }^{1} \mathrm{O}$ exame de suficiência é um requisito do curso de Mestrado profissional que precisa ser realizado durante o curso. Muitos egressos acabam prorrogando o prazo de sua defesa por esse motivo. Esse assunto pode ser investigado em numa outra pesquisa. 
ciências e matemática e Educação Tecnológica abarcando uma diversidade de sublinhas. Como pode ser observado no quadro abaixo:

Quadro 1 - Área de concentração, linha e sublinha do curso de MP

\begin{tabular}{|c|c|}
\hline \multicolumn{2}{|c|}{ Área: Ciência, Tecnologia e Ensino } \\
\hline $\begin{array}{c}\text { Linha } 1 \\
\text { Fundamentos e metodologias } \\
\text { para o ensino de ciências e matemática }\end{array}$ & $\begin{array}{l}\text { Linha } 2 \\
\text { Educação Tecnológica }\end{array}$ \\
\hline Sublinhas: & Sublinhas: \\
\hline Ensino de Biologia & $\begin{array}{c}\text { Desenvolvimento de material } \\
\text { instrucional para a Educação Tecnológica }\end{array}$ \\
\hline Ensino de Química & $\begin{array}{l}\text { Ensino nas Engenharias e nas } \\
\text { Tecnologias }\end{array}$ \\
\hline Ensino de Ciências & $\begin{array}{l}\text { Informática no ensino das ciências e } \\
\text { da tecnologia }\end{array}$ \\
\hline $\begin{array}{l}\text { Ensino de Ciências nas séries } \\
\text { iniciais }\end{array}$ & $\begin{array}{l}\text { Linguagem e cognição no ensino de } \\
\text { ciências e tecnologia }\end{array}$ \\
\hline Ensino de Estatística & $\begin{array}{l}\text { Metodologia da pesquisa aplicada a } \\
\text { Educação Tecnológica }\end{array}$ \\
\hline Ensino de Física & $\begin{array}{l}\text { Relações entre ciência, tecnologia e } \\
\text { sociedade no ensino-aprendizagem }\end{array}$ \\
\hline Ensino de Matemática & \\
\hline
\end{tabular}

(Fonte: $h t t p: / / p p g e c t . p g . u t f p r . e d u . b r / s i t e / ? p a g e_{-} i d=186$ )

Nesta relação, também consta os produtos educacionais ou finais, desenvolvidos pelos pesquisadores se diferenciam no propósito de atender as necessidades singulares de cada contexto de ensino buscando ainda, subsidiar seus pares.

DOI: Em andamento. 
Quadro 2-Dissertações e produtos do Mestrado Profissional em Ensino

de Ciência e Tecnologia disponibilizados no site

referentes ao ano de 2009

\begin{tabular}{|c|c|c|c|c|c|}
\hline LINHA & SUBLINHA & $\begin{array}{l}\text { DISCIPLINA } \\
\text { A QUE SE } \\
\text { APLICA }\end{array}$ & TíTULO & $\begin{array}{l}\text { NÍVEL DE } \\
\text { ENSINO }\end{array}$ & PRODUTO \\
\hline $\begin{array}{l}\text { Fundamentos } \\
\text { e } \\
\text { metodologias } \\
\text { para o ensino } \\
\text { de ciências e } \\
\text { matemática }\end{array}$ & $\begin{array}{l}\text { Ensino de } \\
\text { Física }\end{array}$ & Física & $\begin{array}{c}\text { Problemas } \\
\text { geradores de } \\
\text { discussões: uma } \\
\text { proposta para a } \\
\text { disciplina de física } \\
\text { nos cursos de } \\
\text { engenharia }\end{array}$ & $\begin{array}{l}\text { Ensino } \\
\text { Superior }\end{array}$ & $\begin{array}{l}\text { Manual } \\
\text { didático }\end{array}$ \\
\hline $\begin{array}{l}\text { Fundamentos } \\
\text { e } \\
\text { metodologias } \\
\text { para o ensino } \\
\text { de ciências e } \\
\text { matemática }\end{array}$ & $\begin{array}{l}\text { Ensino de } \\
\text { Química }\end{array}$ & Química & $\begin{array}{l}\text { Uma contribuição } \\
\text { didática do uso do } \\
\text { lúdico para o } \\
\text { processo de ensino- } \\
\text { aprendizagem de } \\
\text { química orgânica } \\
\text { um estudo de caso } \\
\text { no curso de } \\
\text { tecnologia } \\
\text { mecânica na } \\
\text { modalidade } \\
\text { produção industrial } \\
\text { de móveis da } \\
\text { UDESC- Planalto } \\
\text { Norte }\end{array}$ & $\begin{array}{l}\text { Ensino } \\
\text { Superior }\end{array}$ & Kit lúdico \\
\hline $\begin{array}{l}\text { Fundamentos } \\
\text { e } \\
\text { metodologias } \\
\text { para o ensino } \\
\text { de ciências e } \\
\text { matemática }\end{array}$ & $\begin{array}{l}\text { Ensino de } \\
\text { Matemática }\end{array}$ & Matemática & $\begin{array}{c}\text { Matemática } \\
\text { escolar: tendências } \\
\text { metodológicas para } \\
\text { o processo de } \\
\text { ensino- } \\
\text { aprendizagem de } \\
\text { geometria plana }\end{array}$ & $\begin{array}{c}\text { Ensino } \\
\text { Fundamental }\end{array}$ & $\begin{array}{c}\text { Caderno } \\
\text { Pedagógico }\end{array}$ \\
\hline
\end{tabular}


A seguir apresentamos o quadro com os produtos e dissertações referentes ao ano de 2010.

Quadro 3: Dissertações e produtos do Mestrado Profissional em Ensino de Ciência e Tecnologia disponibilizados no

\begin{tabular}{|c|c|c|c|c|c|}
\hline LINHA & SUBLINHA & $\begin{array}{c}\text { DISCIPLINA A } \\
\text { QUE SE } \\
\text { APLICA }\end{array}$ & TÍTULO & AMOSTRA & PRODUTO \\
\hline $\begin{array}{l}\text { Fundamentos e } \\
\text { metodologias } \\
\text { para o ensino } \\
\text { de ciências e } \\
\text { matemática }\end{array}$ & $\begin{array}{l}\text { Ensino de } \\
\text { Matemática }\end{array}$ & Matemática & $\begin{array}{c}\text { Ensino- } \\
\text { aprendizagem } \\
\text { por meio de } \\
\text { projetos } \\
\text { desenvolvidos } \\
\text { por equipes de } \\
\text { responsabilida } \\
\text {-de em sala de } \\
\text { aula: o } \\
\text { enfoque no } \\
\text { ensino de } \\
\text { matemática } \\
\text { nas séries } \\
\text { iniciais }\end{array}$ & $\begin{array}{c}\text { Ensino } \\
\text { Fundamental }\end{array}$ & $\begin{array}{l}\text { Manual } \\
\text { didático }\end{array}$ \\
\hline $\begin{array}{l}\text { Educação } \\
\text { Tecnológica }\end{array}$ & $\begin{array}{l}\text { Informática } \\
\text { no ensino } \\
\text { das ciências } \\
\text { e da } \\
\text { tecnologia }\end{array}$ & Informática & $\begin{array}{c}\text { Ensino de } \\
\text { programação } \\
\text { com ênfase na } \\
\text { solução de } \\
\text { problemas }\end{array}$ & Pós- Médio & $\begin{array}{l}\text { Manual } \\
\text { didático }\end{array}$ \\
\hline $\begin{array}{l}\text { Desenvolviment } \\
\text { o de material } \\
\text { instrucional } \\
\text { para a Educação } \\
\text { Tecnológica }\end{array}$ & $\begin{array}{l}\text { Linguagem e } \\
\text { cognição no } \\
\text { ensino de } \\
\text { ciências e } \\
\text { tecnologia }\end{array}$ & $\begin{array}{c}\text { Educação } \\
\text { Especial }\end{array}$ & $\begin{array}{c}\text { Mobiliário } \\
\text { escolar com } \\
\text { recomendaçõe } \\
\text { s ergonômicas } \\
\text { e recursos da } \\
\text { tecnologia } \\
\text { Assistiva: } \\
\text { adequações }\end{array}$ & $\begin{array}{c}\text { Ensino } \\
\text { Fundamental }\end{array}$ & Mobiliário \\
\hline
\end{tabular}

R. B. E. C. T., vol 8, núm. 3, mai-ago.2015 ISSN - 1982-873X

DOI: Em andamento. 


\begin{tabular}{|c|c|c|c|c|c|}
\hline & & & $\begin{array}{c}\text { para alunos } \\
\text { com baixa } \\
\text { visão }\end{array}$ & & \\
\hline $\begin{array}{l}\text { Fundamentos e } \\
\text { metodologias } \\
\text { para o ensino } \\
\text { de ciências e } \\
\text { matemática }\end{array}$ & $\begin{array}{l}\text { Linguagem e } \\
\text { cognição no } \\
\text { ensino de } \\
\text { ciências e } \\
\text { tecnologia }\end{array}$ & $\begin{array}{l}\text { Ciências e } \\
\text { Matemática }\end{array}$ & $\begin{array}{c}\text { Construção do } \\
\text { conhecimento } \\
\text { em educação } \\
\text { infantil: } \\
\text { sequências } \\
\text { didáticas e } \\
\text { lúdicas para o } \\
\text { ensino de } \\
\text { ciências e } \\
\text { matemática }\end{array}$ & $\begin{array}{c}\text { Ensino } \\
\text { Fundamental }\end{array}$ & $\begin{array}{l}\text { Caderno } \\
\text { Didático }\end{array}$ \\
\hline $\begin{array}{l}\text { Fundamentos e } \\
\text { metodologias } \\
\text { para o ensino } \\
\text { de ciências e } \\
\text { matemática }\end{array}$ & $\begin{array}{c}\text { Ensino de } \\
\text { Física }\end{array}$ & Física & $\begin{array}{l}\text { Conceitos de } \\
\text { física para } \\
\text { crianças: uma } \\
\text { proposta para } \\
\text { as séries } \\
\text { iniciais }\end{array}$ & $\begin{array}{c}\text { Ensino } \\
\text { Fundamental }\end{array}$ & $\begin{array}{l}\text { Manual } \\
\text { Didático }\end{array}$ \\
\hline $\begin{array}{l}\text { Fundamentos e } \\
\text { metodologias } \\
\text { para o ensino } \\
\text { de ciências e } \\
\text { matemática }\end{array}$ & $\begin{array}{l}\text { Ensino de } \\
\text { Matemática }\end{array}$ & Matemática & $\begin{array}{c}\text { Uma } \\
\text { experiência } \\
\text { com a essência } \\
\text { da modelagem } \\
\text { matemática na } \\
\text { construção de } \\
\text { maquete }\end{array}$ & $\begin{array}{l}\text { Ensino } \\
\text { Médio }\end{array}$ & $\begin{array}{c}\text { Sequência } \\
\text { Didática }\end{array}$ \\
\hline $\begin{array}{c}\text { Fundamentos e } \\
\text { metodologias } \\
\text { para o ensino } \\
\text { de ciências e } \\
\text { matemática }\end{array}$ & $\begin{array}{l}\text { Ensino de } \\
\text { Biologia }\end{array}$ & $\begin{array}{c}\text { Ciências e } \\
\text { Biologia }\end{array}$ & $\begin{array}{l}\text { Músicas e } \\
\text { imagens: } \\
\text { recursos de } \\
\text { mídia como } \\
\text { ferramenta } \\
\text { para o ensino } \\
\text { de Ciências e } \\
\text { Biologia }\end{array}$ & $\begin{array}{l}\text { Ensino } \\
\text { Médio }\end{array}$ & $\begin{array}{l}\text { Manual } \\
\text { Didático }\end{array}$ \\
\hline $\begin{array}{c}\text { Fundamentos e } \\
\text { metodologias }\end{array}$ & Ensino de & Biologia & $\begin{array}{l}\text { A dimensão } \\
\text { ambiental no }\end{array}$ & $\begin{array}{l}\text { Ensino } \\
\text { Médio }\end{array}$ & Jogo \\
\hline
\end{tabular}

10 DOI: Em andamento.

R. Bras. de Ensino de C\&T 


\begin{tabular}{|c|c|c|c|c|c|}
\hline $\begin{array}{l}\text { para o ensino } \\
\text { de ciências e } \\
\text { matemática }\end{array}$ & Biologia & & $\begin{array}{c}\text { contexto } \\
\text { ensino- } \\
\text { aprendizagem: } \\
\text { avaliação do } \\
\text { jogo didático } \\
\text { nas aulas de } \\
\text { Biologia }\end{array}$ & & \\
\hline $\begin{array}{l}\text { Fundamentos e } \\
\text { metodologias } \\
\text { para o ensino } \\
\text { de ciências e } \\
\text { matemática }\end{array}$ & $\begin{array}{l}\text { Ensino de } \\
\text { Física }\end{array}$ & Física & $\begin{array}{c}\text { Toda Física por } \\
\text { água abaixo: a } \\
\text { construção e } \\
\text { utilização de } \\
\text { um protótipo } \\
\text { de submarino } \\
\text { para o ensino } \\
\text { de Física }\end{array}$ & $\begin{array}{l}\text { Ensino } \\
\text { Médio }\end{array}$ & Protótipo \\
\hline $\begin{array}{l}\text { Educação } \\
\text { Tecnológica }\end{array}$ & $\begin{array}{l}\text { Ensino nas } \\
\text { Engenharias } \\
\text { e nas } \\
\text { Tecnologias }\end{array}$ & $\begin{array}{l}\text { Ciência dos } \\
\text { Materiais }\end{array}$ & $\begin{array}{c}\text { O uso do blog } \\
\text { e Webquest } \\
\text { como } \\
\text { ferramenta de } \\
\text { aprendizagem } \\
\text { na disciplina } \\
\text { ciência dos } \\
\text { materiais }\end{array}$ & $\begin{array}{l}\text { Ensino } \\
\text { Superior }\end{array}$ & $\begin{array}{c}\text { Roteiro } \\
\text { Webquest }\end{array}$ \\
\hline $\begin{array}{l}\text { Educação } \\
\text { Tecnológica }\end{array}$ & $\begin{array}{c}\text { Relações } \\
\text { entre } \\
\text { ciência, } \\
\text { tecnologia e } \\
\text { sociedade } \\
\text { no ensino- } \\
\text { aprendiza- } \\
\text { gem }\end{array}$ & $\begin{array}{c}\text { Metodologia } \\
\text { de Ensino }\end{array}$ & $\begin{array}{l}\text { A contribuição } \\
\text { das técnicas de } \\
\text { dinâmicas de } \\
\text { grupo para a } \\
\text { formação de } \\
\text { docentes de } \\
\text { nível médio }\end{array}$ & $\begin{array}{l}\text { Ensino } \\
\text { Médio }\end{array}$ & $\begin{array}{c}\text { Guia } \\
\text { Didático }\end{array}$ \\
\hline $\begin{array}{l}\text { Fundamentos e } \\
\text { metodologias } \\
\text { para o ensino } \\
\text { de ciências e } \\
\text { matemática }\end{array}$ & $\begin{array}{l}\text { Ensino de } \\
\text { Física }\end{array}$ & Física & $\begin{array}{l}\text { Percepção da } \\
\text { aptidão física } \\
\text { relacionada à } \\
\text { saúde na } \\
\text { qualidade de } \\
\text { vida: }\end{array}$ & $\begin{array}{l}\text { Ensino } \\
\text { Superior }\end{array}$ & Cartilha \\
\hline
\end{tabular}

R. B. E. C. T., vol 8, núm. 3, mai-ago.2015 ISSN - 1982-873X

DOI: Em andamento. 


\begin{tabular}{|c|c|c|c|c|c|}
\hline & & & $\begin{array}{l}\text { instrumento } \\
\text { de ensino na } \\
\text { disciplina de } \\
\text { qualidade de } \\
\text { vida nos } \\
\text { cursos de } \\
\text { engenharia } \\
\text { elétrica e } \\
\text { mecânica da } \\
\text { UTFPR-CP }\end{array}$ & & \\
\hline $\begin{array}{l}\text { Fundamentos e } \\
\text { metodologias } \\
\text { para o ensino } \\
\text { de ciências e } \\
\text { matemática }\end{array}$ & $\begin{array}{l}\text { Ensino de } \\
\text { Biologia }\end{array}$ & Biologia & $\begin{array}{c}\text { A contribuição } \\
\text { do jogo } \\
\text { didático para o } \\
\text { ensino de } \\
\text { biologia celular }\end{array}$ & $\begin{array}{l}\text { Ensino } \\
\text { Médio }\end{array}$ & Jogo \\
\hline $\begin{array}{l}\text { Educação } \\
\text { Tecnológica }\end{array}$ & $\begin{array}{l}\text { Ensino nas } \\
\text { Engenharias } \\
\text { e nas } \\
\text { Tecnologias }\end{array}$ & $\begin{array}{c}\text { Metodologia } \\
\text { Científica }\end{array}$ & $\begin{array}{l}\text { Instrumento } \\
\text { de revisão } \\
\text { redacional e } \\
\text { metodológica } \\
\text { para aplicação } \\
\text { avaliativa em } \\
\text { trabalhos } \\
\text { acadêmicos }\end{array}$ & $\begin{array}{c}\text { Graduação e } \\
\text { Pós- } \\
\text { Graduação }\end{array}$ & $\begin{array}{c}\text { Lista de } \\
\text { Verificação }\end{array}$ \\
\hline $\begin{array}{l}\text { Fundamentos e } \\
\text { metodologias } \\
\text { para o ensino } \\
\text { de ciências e } \\
\text { matemática }\end{array}$ & $\begin{array}{l}\text { Ensino de } \\
\text { Ciências }\end{array}$ & Ciências & $\begin{array}{c}\text { A pedagogia } \\
\text { de projetos de } \\
\text { investigação } \\
\text { no estudo de } \\
\text { problemas } \\
\text { socioambienta } \\
\text { is: uma } \\
\text { situação de } \\
\text { aprendizagem } \\
\text { na formação } \\
\text { de professores } \\
\text { de ciências }\end{array}$ & Docentes & DVDs \\
\hline $\begin{array}{c}\text { Fundamentos e } \\
\text { metodologias }\end{array}$ & Ensino de & Matemática & $\begin{array}{l}\text { O ensino de } \\
\text { potências e }\end{array}$ & Ensino & Apostila \\
\hline
\end{tabular}

12 DOI: Em andamento.

R. Bras. de Ensino de C\&T 


\begin{tabular}{|c|c|c|c|c|c|}
\hline para o ensino & Matemática & & suas & Fundamental \\
de ciências e & & propriedades: & \\
matemática & & um enfoque à & \\
& & & luz das \\
& & & neurociências & & \\
\hline
\end{tabular}

O quadro 4 apresenta as dissertações e produtos disponibilizados no site referentes ao no de 2011.

Quadro 4-Dissertações e produtos do Mestrado Profissional em Ensino de Ciência e Tecnologia disponibilizados no site

referentes ao ano de 2011.

\begin{tabular}{|c|c|c|c|c|c|}
\hline LINHA & SUBLINHA & $\begin{array}{c}\text { DISCIPLINA } \\
\text { A QUE SE } \\
\text { APLICA }\end{array}$ & TÍTULO & AMOSTRA & PRODUTO \\
\hline $\begin{array}{l}\text { Fundamentos } \\
\text { e } \\
\text { metodologias } \\
\text { para o ensino } \\
\text { de ciências e } \\
\text { matemática }\end{array}$ & $\begin{array}{l}\text { Ensino de } \\
\text { Matemática }\end{array}$ & Matemática & $\begin{array}{l}\text { O ensino da } \\
\text { Matemática } \\
\text { nos anos } \\
\text { iniciais: uma } \\
\text { abordagem a } \\
\text { partir de um } \\
\text { tema gerador }\end{array}$ & $\begin{array}{l}\text { Ensino } \\
\text { Funda- } \\
\text { mental }\end{array}$ & $\begin{array}{l}\text { Manual } \\
\text { Didático }\end{array}$ \\
\hline $\begin{array}{l}\text { Fundamentos } \\
\text { e } \\
\text { metodologias } \\
\text { para o ensino } \\
\text { de ciências e } \\
\text { matemática }\end{array}$ & $\begin{array}{l}\text { Ensino de } \\
\text { Matemática }\end{array}$ & Matemática & $\begin{array}{c}\text { A bandeira } \\
\text { nacional na } \\
\text { medida certa: } \\
\text { um olhar para } \\
\text { o ensino } \\
\text { contextualizad } \\
\text { o de } \\
\text { geometria }\end{array}$ & $\begin{array}{l}\text { Ensino } \\
\text { Funda- } \\
\text { mental }\end{array}$ & $\begin{array}{l}\text { Manual } \\
\text { Didático }\end{array}$ \\
\hline $\begin{array}{l}\text { Fundamentos } \\
\text { e } \\
\text { metodologias } \\
\text { para o ensino } \\
\text { de ciências e }\end{array}$ & $\begin{array}{c}\text { Ensino de } \\
\text { Física }\end{array}$ & Física & $\begin{array}{l}\text { Curta de } \\
\text { animação } \\
\text { como } \\
\text { organizador } \\
\text { prévio no } \\
\text { ensino de }\end{array}$ & $\begin{array}{l}\text { Ensino } \\
\text { Médio }\end{array}$ & $\begin{array}{c}\text { Curta } \\
\text { Metragem }\end{array}$ \\
\hline
\end{tabular}

R. B. E. C. T., vol 8, núm. 3, mai-ago.2015 ISSN - 1982-873X

DOI: Em andamento. 


\begin{tabular}{|c|c|c|c|c|c|}
\hline matemática & & & física & & \\
\hline $\begin{array}{l}\text { Fundamentos } \\
\text { e } \\
\text { metodologias } \\
\text { para o ensino } \\
\text { de ciências e } \\
\text { matemática }\end{array}$ & $\begin{array}{c}\text { Relações entre } \\
\text { ciência, } \\
\text { tecnologia e } \\
\text { sociedade no } \\
\text { ensino- } \\
\text { aprendizagem }\end{array}$ & $\begin{array}{l}\text { Primeiros } \\
\text { Socorros }\end{array}$ & $\begin{array}{c}\text { O uso de um } \\
\text { objeto de } \\
\text { aprendizagem } \\
\text { na disciplina } \\
\text { de primeiros } \\
\text { socorros }\end{array}$ & Pós-Médio & $\begin{array}{c}\text { Objeto de } \\
\text { Aprendizage } \\
\text { m }\end{array}$ \\
\hline $\begin{array}{l}\text { Fundamentos } \\
\text { e } \\
\text { metodologias } \\
\text { para o ensino } \\
\text { de ciências e } \\
\text { matemática }\end{array}$ & $\begin{array}{c}\text { Ensino de } \\
\text { Matemática }\end{array}$ & Matemática & $\begin{array}{c}\text { O ajuste de } \\
\text { funções à luz } \\
\text { da modelagem } \\
\text { matemática }\end{array}$ & $\begin{array}{l}\text { Ensino } \\
\text { Superior }\end{array}$ & $\begin{array}{c}\text { Caderno } \\
\text { Pedagógico }\end{array}$ \\
\hline $\begin{array}{l}\text { Educação } \\
\text { Tecnológica }\end{array}$ & $\begin{array}{l}\text { Informática no } \\
\text { ensino das } \\
\text { ciências e da } \\
\text { tecnologia }\end{array}$ & Informática & $\begin{array}{c}\text { Robótica: } \\
\text { ferramenta } \\
\text { pedagógica no } \\
\text { campo da } \\
\text { computação }\end{array}$ & Pós-Médio & $\begin{array}{l}\text { Manual } \\
\text { Didático }\end{array}$ \\
\hline $\begin{array}{l}\text { Fundamentos } \\
\text { e } \\
\text { metodologias } \\
\text { para o ensino } \\
\text { de ciências e } \\
\text { matemática }\end{array}$ & $\begin{array}{l}\text { Ensino de } \\
\text { Ciências }\end{array}$ & Ciências & $\begin{array}{c}\text { Oficinas em } \\
\text { educação } \\
\text { ambiental no } \\
\text { ensino } \\
\text { fundamental: } \\
\text { redução, } \\
\text { reutilização e } \\
\text { reciclagem de } \\
\text { materiais }\end{array}$ & $\begin{array}{l}\text { Ensino } \\
\text { Funda- } \\
\text { mental }\end{array}$ & $\begin{array}{l}\text { Caderno } \\
\text { temático }\end{array}$ \\
\hline $\begin{array}{l}\text { Fundamentos } \\
\text { e } \\
\text { metodologias } \\
\text { para o ensino } \\
\text { de ciências e } \\
\text { matemática }\end{array}$ & $\begin{array}{c}\text { Desenvolvime } \\
\text { n-to de } \\
\text { material } \\
\text { instrucional } \\
\text { para a } \\
\text { Educação } \\
\text { Tecnológica }\end{array}$ & Saúde & $\begin{array}{l}\text { Detetive da } \\
\text { saúde: um } \\
\text { jogo de } \\
\text { tabuleiro e sua } \\
\text { contribuição } \\
\text { para o ensino } \\
\text { e a } \\
\text { aprendizagem }\end{array}$ & $\begin{array}{l}\text { Ensino } \\
\text { Médio }\end{array}$ & Jogo \\
\hline
\end{tabular}

14 DOI: Em andamento.

R. Bras. de Ensino de C\&T 


\begin{tabular}{|c|c|c|c|c|c|}
\hline & & & $\begin{array}{l}\text { na área da } \\
\text { saúde }\end{array}$ & & \\
\hline $\begin{array}{c}\text { Fundamentos } \\
\text { e } \\
\text { metodologias } \\
\text { para o ensino } \\
\text { de ciências e } \\
\text { matemática }\end{array}$ & $\begin{array}{l}\text { Ensino de } \\
\text { Ciências }\end{array}$ & Ciências & $\begin{array}{c}\text { Contribuições } \\
\text { do material } \\
\text { em libras para } \\
\text { o ensino de } \\
\text { ciências na } \\
\text { educação } \\
\text { infantil }\end{array}$ & $\begin{array}{c}\text { Educação } \\
\text { Infantil }\end{array}$ & Ficha \\
\hline $\begin{array}{l}\text { Educação } \\
\text { Tecnológica }\end{array}$ & $\begin{array}{l}\text { Relações entre } \\
\text { ciência, } \\
\text { tecnologia e } \\
\text { sociedade no } \\
\text { ensino- } \\
\text { aprendizagem }\end{array}$ & Ciências & $\begin{array}{c}\text { O ensino de } \\
\text { ciências nos } \\
\text { anos iniciais } \\
\text { do ensino } \\
\text { fundamental } \\
\text { sob a ótica } \\
\text { CTS: uma } \\
\text { proposta de } \\
\text { trabalho } \\
\text { diante dos } \\
\text { artefatos } \\
\text { tecnológicos } \\
\text { que norteiam } \\
\text { o cotidiano } \\
\text { dos alunos }\end{array}$ & $\begin{array}{l}\text { Ensino } \\
\text { Funda- } \\
\text { mental }\end{array}$ & Guia Didático \\
\hline
\end{tabular}

O quadro 5 apresenta as dissertações e produtos disponibilizados no site referentes ao ano de 2012.

Quadro 5: Dissertações e produtos do Mestrado Profissional em Ensino de Ciência e Tecnologia disponibilizados no site

referentes ao ano de 2012.

\begin{tabular}{|c|c|c|c|c|c|}
\hline LINHA & SUBLINHA & $\begin{array}{c}\text { DISCIPLINA } \\
\text { A QUE SE } \\
\text { APLICA }\end{array}$ & TíTULO & AMOSTRA & PRODUTO \\
\hline Educação & $\begin{array}{c}\text { Informática no } \\
\text { ensino das }\end{array}$ & Informática & $\begin{array}{c}\text { Um jogo } \\
\text { eletrônico como }\end{array}$ & Ensino & Jogo \\
\hline
\end{tabular}

R. B. E. C. T., vol 8, núm. 3, mai-ago.2015 ISSN - 1982-873X

DOI: Em andamento. 


\begin{tabular}{|c|c|c|c|c|c|}
\hline Tecnológica & $\begin{array}{c}\text { ciências e da } \\
\text { tecnologia }\end{array}$ & & $\begin{array}{c}\text { ferramenta } \\
\text { complementar } \\
\text { no ensino de } \\
\text { PHP }\end{array}$ & Superior & \\
\hline $\begin{array}{l}\text { Fundamentos } \\
\text { e } \\
\text { metodologias } \\
\text { para o ensino } \\
\text { de ciências e } \\
\text { matemática }\end{array}$ & $\begin{array}{l}\text { Ensino de } \\
\text { Matemática }\end{array}$ & Matemática & $\begin{array}{c}\text { Uma proposta } \\
\text { metodológica } \\
\text { para o ensino de } \\
\text { Geometria } \\
\text { Fractal em sala } \\
\text { de aula na } \\
\text { Educação básica }\end{array}$ & $\begin{array}{l}\text { Ensino } \\
\text { Médio }\end{array}$ & $\begin{array}{l}\text { Caderno } \\
\text { Pedagógico }\end{array}$ \\
\hline $\begin{array}{l}\text { Educação } \\
\text { Tecnológica }\end{array}$ & $\begin{array}{c}\text { Relações entre } \\
\text { ciência, } \\
\text { tecnologia e } \\
\text { sociedade no } \\
\text { ensino- } \\
\text { aprendizagem }\end{array}$ & Biologia & $\begin{array}{c}\text { Reflexões sobre } \\
\text { ciência e } \\
\text { tecnologia e } \\
\text { suas implicações } \\
\text { sociais em aulas } \\
\text { de botânica } \\
\text { aplicada à } \\
\text { farmacologia }\end{array}$ & Pós-Médio & $\begin{array}{c}\text { Guia } \\
\text { Didático }\end{array}$ \\
\hline $\begin{array}{l}\text { Fundamentos } \\
\text { e } \\
\text { metodologias } \\
\text { para o ensino } \\
\text { de ciências e } \\
\text { matemática }\end{array}$ & $\begin{array}{l}\text { Ensino de } \\
\text { Matemática }\end{array}$ & Matemática & $\begin{array}{c}\text { Projetos de } \\
\text { trabalho: uma } \\
\text { contribuição } \\
\text { para o ensino e } \\
\text { aprendizagem } \\
\text { de matemática } \\
\text { no ensino } \\
\text { fundamental }\end{array}$ & $\begin{array}{c}\text { Ensino } \\
\text { Fundamental }\end{array}$ & $\begin{array}{l}\text { Manual } \\
\text { Didático }\end{array}$ \\
\hline $\begin{array}{l}\text { Educação } \\
\text { Tecnológica }\end{array}$ & $\begin{array}{l}\text { Linguagem e } \\
\text { cognição no } \\
\text { ensino de } \\
\text { ciências e } \\
\text { tecnologia }\end{array}$ & Ciências & $\begin{array}{c}\text { Práticas } \\
\text { pedagógicas: a } \\
\text { construção do } \\
\text { saber sobre } \\
\text { resíduos sólidos } \\
\text { em uma escola } \\
\text { rural }\end{array}$ & $\begin{array}{c}\text { Ensino } \\
\text { Fundamental }\end{array}$ & $\begin{array}{c}\text { Guia de } \\
\text { Atividades }\end{array}$ \\
\hline $\begin{array}{l}\text { Educação } \\
\text { Tecnológica }\end{array}$ & $\begin{array}{c}\text { Informática no } \\
\text { ensino das }\end{array}$ & Informática & $\begin{array}{c}\text { OCTAVE: uma } \\
\text { proposta para o }\end{array}$ & $\begin{array}{l}\text { Ensino } \\
\text { Médio }\end{array}$ & $\begin{array}{l}\text { Manual } \\
\text { Didático }\end{array}$ \\
\hline
\end{tabular}

16 DOI: Em andamento.

R. Bras. de Ensino de C\&T 


\begin{tabular}{|c|c|c|c|c|c|}
\hline & $\begin{array}{c}\text { ciências e da } \\
\text { tecnologia }\end{array}$ & & $\begin{array}{l}\text { ensino de } \\
\text { funções }\end{array}$ & & \\
\hline $\begin{array}{l}\text { Educação } \\
\text { Tecnológica }\end{array}$ & $\begin{array}{l}\text { Metodologia da } \\
\text { pesquisa } \\
\text { aplicada a } \\
\text { Educação } \\
\text { Tecnológica }\end{array}$ & $\begin{array}{c}\text { Educação } \\
\text { Física }\end{array}$ & $\begin{array}{c}\text { Construção de } \\
\text { uma biblioteca } \\
\text { digital } \\
\text { especializada } \\
\text { voltada para a } \\
\text { disseminação de } \\
\text { informações do } \\
\text { tema qualidade } \\
\text { de vida nos } \\
\text { cursos de } \\
\text { engenharia da } \\
\text { UTFPR }\end{array}$ & $\begin{array}{l}\text { Ensino } \\
\text { Superior }\end{array}$ & $\begin{array}{c}\text { Biblioteca } \\
\text { Digital }\end{array}$ \\
\hline $\begin{array}{l}\text { Fundamentos } \\
\text { e } \\
\text { metodologias } \\
\text { para o ensino } \\
\text { de ciências e } \\
\text { matemática }\end{array}$ & $\begin{array}{l}\text { Ensino de } \\
\text { Matemática }\end{array}$ & Matemática & $\begin{array}{c}\text { Utilização de } \\
\text { Caleidociclos no } \\
\text { ensino de } \\
\text { geometria: uma } \\
\text { proposta } \\
\text { metodológica } \\
\text { para o ensino } \\
\text { médio }\end{array}$ & $\begin{array}{l}\text { Ensino } \\
\text { Médio }\end{array}$ & $\begin{array}{c}\text { Sequência } \\
\text { Didática }\end{array}$ \\
\hline $\begin{array}{l}\text { Fundamentos } \\
\text { e } \\
\text { metodologias } \\
\text { para o ensino } \\
\text { de ciências e } \\
\text { matemática }\end{array}$ & $\begin{array}{l}\text { Ensino de } \\
\text { Química }\end{array}$ & Química & $\begin{array}{c}\text { O ensino da } \\
\text { função orgânica } \\
\text { álcool por meio } \\
\text { de } \\
\text { experimentação } \\
\text { numa } \\
\text { abordagem } \\
\text { Ciência, } \\
\text { Tecnologia e } \\
\text { Sociedade (CTS) }\end{array}$ & $\begin{array}{l}\text { Ensino } \\
\text { Médio }\end{array}$ & $\begin{array}{c}\text { Sequência } \\
\text { Didática }\end{array}$ \\
\hline $\begin{array}{l}\text { Educação } \\
\text { Tecnológica }\end{array}$ & $\begin{array}{c}\text { Relações entre } \\
\text { ciência, } \\
\text { tecnologia e } \\
\text { sociedade no } \\
\text { ensino- }\end{array}$ & Psicologia & $\begin{array}{c}\text { Ensino de } \\
\text { psicologia } \\
\text { organizacional } \\
\text { em cursos da } \\
\text { área }\end{array}$ & Pós-Médio & $\begin{array}{c}\text { Guia } \\
\text { Didático }\end{array}$ \\
\hline
\end{tabular}

R. B. E. C. T., vol 8, núm. 3, mai-ago.2015 ISSN - 1982-873X

DOI: Em andamento. 


\begin{tabular}{|c|c|c|c|c|c|}
\hline & aprendizagem & & $\begin{array}{l}\text { tecnológica: o } \\
\text { que é e o que } \\
\text { pode ser }\end{array}$ & & \\
\hline $\begin{array}{c}\text { Fundamentos } \\
\text { e } \\
\text { metodologias } \\
\text { para o ensino } \\
\text { de ciências e } \\
\text { matemática }\end{array}$ & $\begin{array}{l}\text { Ensino de } \\
\text { Ciências }\end{array}$ & Ciências & $\begin{array}{l}\text { A construção de } \\
\text { um software } \\
\text { multimídia para } \\
\text { o ensino de } \\
\text { ciências: uma } \\
\text { contribuição ao } \\
\text { aprendizado de } \\
\text { angiospermas }\end{array}$ & $\begin{array}{c}\text { Ensino } \\
\text { Fundamental }\end{array}$ & Software \\
\hline $\begin{array}{l}\text { Fundamentos } \\
\text { e } \\
\text { metodologias } \\
\text { para o ensino } \\
\text { de ciências e } \\
\text { matemática }\end{array}$ & $\begin{array}{l}\text { Ensino de } \\
\text { Física }\end{array}$ & Física & $\begin{array}{l}\text { Telefone celular } \\
\text { como um } \\
\text { recurso didático: } \\
\text { possibilidades } \\
\text { para mediar } \\
\text { práticas do } \\
\text { ensino de Física }\end{array}$ & Docentes & Livro \\
\hline $\begin{array}{l}\text { Fundamentos } \\
\text { e } \\
\text { metodologias } \\
\text { para o ensino } \\
\text { de ciências e } \\
\text { matemática }\end{array}$ & $\begin{array}{l}\text { Ensino de } \\
\text { Matemática }\end{array}$ & Matemática & $\begin{array}{l}\text { Pró-letramento } \\
\text { em matemática: } \\
\text { problematizando } \\
\text { a construção do } \\
\text { conceito de } \\
\text { frações - uma } \\
\text { contribuição } \\
\text { para a formação } \\
\text { de professores }\end{array}$ & $\begin{array}{c}\text { Ensino } \\
\text { Fundamental }\end{array}$ & $\begin{array}{c}\text { Caderno } \\
\text { Pedagógico }\end{array}$ \\
\hline $\begin{array}{c}\text { Fundamentos } \\
\text { e } \\
\text { metodologias } \\
\text { para o ensino } \\
\text { de ciências e } \\
\text { matemática }\end{array}$ & $\begin{array}{l}\text { Ensino de } \\
\text { Matemática }\end{array}$ & Matemática & $\begin{array}{l}\text { Modelagem } \\
\text { matemática } \\
\text { como estratégia } \\
\text { de ensino e } \\
\text { aprendizagem: } \\
\text { uma perspectiva } \\
\text { à luz dos futuros } \\
\text { professores de } \\
\text { Matemática }\end{array}$ & $\begin{array}{l}\text { Ensino } \\
\text { Superior }\end{array}$ & $\begin{array}{c}\text { Caderno } \\
\text { Pedagógico }\end{array}$ \\
\hline
\end{tabular}

18 DOI: Em andamento.

R. Bras. de Ensino de C\&T 


\begin{tabular}{|c|c|c|c|c|c|}
\hline $\begin{array}{l}\text { Educação } \\
\text { Tecnológica }\end{array}$ & $\begin{array}{l}\text { Relações entre } \\
\text { ciência, } \\
\text { tecnologia e } \\
\text { sociedade no } \\
\text { ensino- } \\
\text { aprendizagem }\end{array}$ & Química & $\begin{array}{c}\text { O estudo dos } \\
\text { elementos } \\
\text { químicos numa } \\
\text { abordagem } \\
\text { Ciência, } \\
\text { Tecnologia e } \\
\text { Sociedade }\end{array}$ & $\begin{array}{l}\text { Ensino } \\
\text { Médio }\end{array}$ & $\begin{array}{c}\text { Guia } \\
\text { Didático }\end{array}$ \\
\hline $\begin{array}{c}\text { Fundamentos } \\
\text { e } \\
\text { metodologias } \\
\text { para o ensino } \\
\text { de ciências e } \\
\text { matemática }\end{array}$ & $\begin{array}{l}\text { Ensino de } \\
\text { Química }\end{array}$ & Química & $\begin{array}{l}\text { Ensino de } \\
\text { soluções } \\
\text { químicas por } \\
\text { meio da } \\
\text { abordagem } \\
\text { Ciência- } \\
\text { Tecnologia- } \\
\text { Sociedade (CTS) }\end{array}$ & $\begin{array}{l}\text { Ensino } \\
\text { Médio }\end{array}$ & $\begin{array}{c}\text { Guia } \\
\text { Didático }\end{array}$ \\
\hline $\begin{array}{l}\text { Educação } \\
\text { Tecnológica }\end{array}$ & $\begin{array}{c}\text { Ensino nas } \\
\text { Engenharias e } \\
\text { nas Tecnologias }\end{array}$ & Química & $\begin{array}{l}\text { O Lúdico como } \\
\text { motivador da } \\
\text { aprendizagem } \\
\text { química para } \\
\text { alunos da 1ạ } \\
\text { série do Ensino } \\
\text { Médio do } \\
\text { Colégio Estadual } \\
\text { João XXIII em } \\
\text { Irati - Paraná }\end{array}$ & $\begin{array}{l}\text { Ensino } \\
\text { Médio }\end{array}$ & Jogo \\
\hline $\begin{array}{c}\text { Fundamentos } \\
\text { e } \\
\text { metodologias } \\
\text { para o ensino } \\
\text { de ciências e } \\
\text { matemática }\end{array}$ & $\begin{array}{l}\text { Ensino de } \\
\text { Matemática }\end{array}$ & Matemática & $\begin{array}{l}\text { O ensino de } \\
\text { medidas de } \\
\text { áreas com o } \\
\text { enfoque CTS }\end{array}$ & $\begin{array}{l}\text { Ensino } \\
\text { Superior }\end{array}$ & $\begin{array}{c}\text { Caderno } \\
\text { Pedagógico }\end{array}$ \\
\hline $\begin{array}{c}\text { Fundamentos } \\
\text { e } \\
\text { metodologias } \\
\text { para o ensino } \\
\text { de ciências e }\end{array}$ & $\begin{array}{l}\text { Ensino de } \\
\text { Ciências }\end{array}$ & Ciências & $\begin{array}{c}\text { O blog como } \\
\text { instrumentação } \\
\text { para professor } \\
\text { de Ciências das } \\
\text { séries iniciais }\end{array}$ & Docentes & Blog \\
\hline
\end{tabular}

R. B. E. C. T., vol 8, núm. 3, mai-ago.2015 ISSN - 1982-873X

DOI: Em andamento. 


\begin{tabular}{|c|c|c|c|c|c|}
\hline matemática & & & & & \\
\hline $\begin{array}{c}\text { Fundamentos } \\
\text { e } \\
\text { metodologias } \\
\text { para o ensino } \\
\text { de ciências e } \\
\text { matemática }\end{array}$ & $\begin{array}{l}\text { Ensino de } \\
\text { Ciências }\end{array}$ & Ciências & $\begin{array}{c}\text { O ensino de } \\
\text { Ciências na pré- } \\
\text { escola a partir } \\
\text { da literatura } \\
\text { infantil: uma } \\
\text { proposta de } \\
\text { sequência } \\
\text { didática }\end{array}$ & $\begin{array}{c}\text { Educação } \\
\text { Infantil }\end{array}$ & $\begin{array}{l}\text { Sequência } \\
\text { Didática }\end{array}$ \\
\hline $\begin{array}{l}\text { Educação } \\
\text { Tecnológica }\end{array}$ & $\begin{array}{l}\text { Linguagem e } \\
\text { cognição no } \\
\text { ensino de } \\
\text { ciências e } \\
\text { tecnologia }\end{array}$ & Ciências & $\begin{array}{c}\text { A agenda } 21 \\
\text { brasileira no } \\
\text { cotidiano escolar }\end{array}$ & $\begin{array}{c}\text { Ensino } \\
\text { Fundamental }\end{array}$ & $\begin{array}{l}\text { Caderno } \\
\text { Temático }\end{array}$ \\
\hline $\begin{array}{l}\text { Educação } \\
\text { Tecnológica }\end{array}$ & $\begin{array}{c}\text { Metodologia da } \\
\text { pesquisa } \\
\text { aplicada a } \\
\text { Educação } \\
\text { Tecnológica }\end{array}$ & Informática & $\begin{array}{c}\text { O uso de } \\
\text { emissora de } \\
\text { rádio como uma } \\
\text { tecnologia de } \\
\text { informação e } \\
\text { comunicação } \\
\text { para a } \\
\text { implementação } \\
\text { do ensino }\end{array}$ & $\begin{array}{c}\text { Ensino } \\
\text { Fundamental }\end{array}$ & Vídeo \\
\hline $\begin{array}{c}\text { Fundamentos } \\
\text { e } \\
\text { metodologias } \\
\text { para o ensino } \\
\text { de ciências e } \\
\text { matemática }\end{array}$ & $\begin{array}{c}\text { Ensino } \\
\text { de } \\
\text { Matemática }\end{array}$ & Matemática & $\begin{array}{c}\text { O ensino de } \\
\text { Matemática nos } \\
\text { anos iniciais do } \\
\text { ensino } \\
\text { fundamental } \\
\text { numa } \\
\text { perspectiva } \\
\text { interdisciplinar }\end{array}$ & $\begin{array}{c}\text { Ensino } \\
\text { Fundamental }\end{array}$ & $\begin{array}{c}\text { Caderno } \\
\text { Pedagógico }\end{array}$ \\
\hline $\begin{array}{c}\text { Fundamentos } \\
\text { e } \\
\text { metodologias } \\
\text { para o ensino } \\
\text { de ciências e }\end{array}$ & $\begin{array}{l}\text { Ensino de } \\
\text { Ciências }\end{array}$ & Ciências & $\begin{array}{l}\text { Histórias em } \\
\text { quadrinhos no } \\
\text { ensino de } \\
\text { ciências: uma } \\
\text { experiência para }\end{array}$ & $\begin{array}{c}\text { Ensino } \\
\text { Fundamental }\end{array}$ & Roteiro \\
\hline
\end{tabular}




\begin{tabular}{|c|c|c|c|c|c|}
\hline matemática & & & $\begin{array}{c}\text { o ensino do } \\
\text { sistema nervoso }\end{array}$ & & \\
\hline $\begin{array}{l}\text { Fundamentos } \\
\text { e } \\
\text { metodologias } \\
\text { para o ensino } \\
\text { de ciências e } \\
\text { matemática }\end{array}$ & $\begin{array}{l}\text { Ensino de } \\
\text { Matemática }\end{array}$ & Matemática & $\begin{array}{l}\text { Contextualização } \\
\text { no ensino de } \\
\text { estatística: uma } \\
\text { proposta para os } \\
\text { anos finais do } \\
\text { Ensino } \\
\text { Fundamental }\end{array}$ & $\begin{array}{c}\text { Ensino } \\
\text { Fundamental }\end{array}$ & $\begin{array}{l}\text { Material } \\
\text { Didático }\end{array}$ \\
\hline $\begin{array}{l}\text { Fundamentos } \\
\text { e } \\
\text { metodologias } \\
\text { para o ensino } \\
\text { de ciências e } \\
\text { matemática }\end{array}$ & $\begin{array}{l}\text { Ensino de } \\
\text { Ciências e } \\
\text { Matemática }\end{array}$ & $\begin{array}{l}\text { Ciências e } \\
\text { Matemática }\end{array}$ & $\begin{array}{l}\text { A integração do } \\
\text { ensino de } \\
\text { Ciências e da } \\
\text { matemática nos } \\
\text { anos iniciais do } \\
\text { Ensino } \\
\text { Fundamental }\end{array}$ & $\begin{array}{c}\text { Ensino } \\
\text { Fundamental }\end{array}$ & $\begin{array}{l}\text { Sequência } \\
\text { de Ensino }\end{array}$ \\
\hline $\begin{array}{l}\text { Educação } \\
\text { Tecnológica }\end{array}$ & $\begin{array}{l}\text { Desenvolvimento } \\
\text { de material } \\
\text { instrucional para } \\
\text { a Educação } \\
\text { Tecnológica }\end{array}$ & Informática & $\begin{array}{l}\text { A utilização de } \\
\text { mapas } \\
\text { conceituais } \\
\text { como apoio ao } \\
\text { ensino de } \\
\text { análise de } \\
\text { requisitos de } \\
\text { software }\end{array}$ & Pós-Médio & $\begin{array}{l}\text { Manual } \\
\text { Didático }\end{array}$ \\
\hline
\end{tabular}

O quadro 6 apresenta as dissertações e produtos disponibilizados no site referentes ao ano de 2013.

Quadro 6: Dissertações e produtos do Mestrado Profissional em Ensino de Ciência e Tecnologia disponibilizados no site referentes ao ano de 2013.

\begin{tabular}{|c|c|c|c|c|c|}
\hline LINHA & SUBLINHA & $\begin{array}{c}\text { DISCIPLINA } \\
\text { A QUE SE } \\
\text { APLICA }\end{array}$ & TÍTULO & AMOSTRA & PRODUTO \\
\hline Fundamentos & Ensino de & Ciências & O uso de & Ensino & Sequência \\
\hline
\end{tabular}

R. B. E. C. T., vol 8, núm. 3, mai-ago.2015 ISSN - 1982-873X

DOI: Em andamento. 


\begin{tabular}{|c|c|c|c|c|c|}
\hline $\begin{array}{c}\text { e } \\
\text { metodologias } \\
\text { para o ensino } \\
\text { de ciências e } \\
\text { matemática }\end{array}$ & Ciências & & $\begin{array}{c}\text { temas } \\
\text { cotidianos } \\
\text { para o ensino } \\
\text { de ciências } \\
\text { nos anos } \\
\text { iniciais do } \\
\text { ensino } \\
\text { fundamental }\end{array}$ & Fundamental & Didática \\
\hline $\begin{array}{l}\text { Fundamentos } \\
\text { e } \\
\text { metodologias } \\
\text { para o ensino } \\
\text { de ciências e } \\
\text { matemática }\end{array}$ & $\begin{array}{l}\text { Ensino de } \\
\text { Física }\end{array}$ & Física & $\begin{array}{c}\text { Sequência } \\
\text { didática para o } \\
\text { ensino de } \\
\text { ciências nos } \\
\text { anos iniciais: } \\
\text { subsídios } \\
\text { teórico- } \\
\text { práticos para a } \\
\text { iniciação à } \\
\text { alfabetização } \\
\text { científica }\end{array}$ & $\begin{array}{l}\text { Ensino } \\
\text { Médio }\end{array}$ & Roteiro \\
\hline $\begin{array}{l}\text { Educação } \\
\text { Tecnológica }\end{array}$ & $\begin{array}{c}\text { Desenvolvimento } \\
\text { de material } \\
\text { instrucional para } \\
\text { a Educação } \\
\text { Tecnológica }\end{array}$ & Ciências & $\begin{array}{c}\text { Ensino da } \\
\text { física e } \\
\text { aprendizagem } \\
\text { significativa: } \\
\text { roteiro para a } \\
\text { elaboração de } \\
\text { uma aula }\end{array}$ & $\begin{array}{c}\text { Ensino } \\
\text { Fundamental }\end{array}$ & Roteiro \\
\hline $\begin{array}{l}\text { Fundamentos } \\
\text { e } \\
\text { metodologias } \\
\text { para o ensino } \\
\text { de ciências e } \\
\text { matemática }\end{array}$ & $\begin{array}{l}\text { Ensino de } \\
\text { Ciências }\end{array}$ & $\begin{array}{l}\text { Educação } \\
\text { Especial }\end{array}$ & $\begin{array}{c}\text { O uso das } \\
\text { tecnologias de } \\
\text { informação e } \\
\text { comunicação } \\
\text { como } \\
\text { ferramentas } \\
\text { no ensino de } \\
\text { Ciências: uma } \\
\text { proposta de } \\
\text { trabalho } \\
\text { interdisciplinar }\end{array}$ & $\begin{array}{l}\text { Ensino } \\
\text { Fundamental }\end{array}$ & $\begin{array}{c}\text { Sequência } \\
\text { Didática }\end{array}$ \\
\hline
\end{tabular}




\begin{tabular}{|c|c|c|c|c|c|}
\hline & & & $\begin{array}{c}\text { nos anos } \\
\text { iniciais do } \\
\text { Ensino } \\
\text { Fundamental }\end{array}$ & & \\
\hline $\begin{array}{l}\text { Fundamentos } \\
\text { e } \\
\text { metodologias } \\
\text { para o ensino } \\
\text { de ciências e } \\
\text { matemática }\end{array}$ & $\begin{array}{l}\text { Ensino de } \\
\text { Matemática }\end{array}$ & Matemática & $\begin{array}{c}\text { Atividades } \\
\text { pedagógicas } \\
\text { de inclusão } \\
\text { para o aluno } \\
\text { com } \\
\text { necessidades } \\
\text { educativas } \\
\text { especiais: uma } \\
\text { proposta } \\
\text { colaborativa } \\
\text { com docentes } \\
\text { em formação }\end{array}$ & $\begin{array}{l}\text { Ensino } \\
\text { Médio }\end{array}$ & $\begin{array}{c}\text { Manual } \\
\text { Pedagógico }\end{array}$ \\
\hline $\begin{array}{l}\text { Fundamentos } \\
\text { e } \\
\text { metodologias } \\
\text { para o ensino } \\
\text { de ciências e } \\
\text { matemática }\end{array}$ & $\begin{array}{l}\text { Ensino de } \\
\text { Matemática }\end{array}$ & Lazer & $\begin{array}{l}\text { Ensino de } \\
\text { geometrias } \\
\text { não- } \\
\text { euclidianas } \\
\text { usando arte e } \\
\text { matemática }\end{array}$ & $\begin{array}{l}\text { Ensino } \\
\text { Superior }\end{array}$ & $\begin{array}{c}\text { Manual e } \\
\text { vídeo } \\
\text { Didático }\end{array}$ \\
\hline $\begin{array}{l}\text { Educação } \\
\text { tecnológica }\end{array}$ & $\begin{array}{l}\text { Desenvolvimento } \\
\text { de material } \\
\text { instrucional para } \\
\text { a Educação } \\
\text { Tecnológica }\end{array}$ & Ciências & $\begin{array}{c}\text { Percepções de } \\
\text { estudantes } \\
\text { universitários } \\
\text { da área } \\
\text { tecnológica } \\
\text { em relação ao } \\
\text { uso da dança } \\
\text { de salão } \\
\text { "Sertanejo } \\
\text { Universitário" } \\
\text { no lazer }\end{array}$ & $\begin{array}{l}\text { Ensino } \\
\text { Fundamental }\end{array}$ & $\begin{array}{c}\text { Sequência } \\
\text { Didática }\end{array}$ \\
\hline $\begin{array}{l}\text { Fundamentos } \\
\text { e } \\
\text { metodologias } \\
\text { para o ensino }\end{array}$ & $\begin{array}{l}\text { Ensino de } \\
\text { Química }\end{array}$ & Química & $\begin{array}{l}\text { O ensino da } \\
\text { função } \\
\text { orgânica } \\
\text { amina por }\end{array}$ & $\begin{array}{l}\text { Ensino } \\
\text { Médio }\end{array}$ & Jogo \\
\hline
\end{tabular}

R. B. E. C. T., vol 8, núm. 3, mai-ago.2015 ISSN - 1982-873X

DOI: Em andamento. 


\begin{tabular}{|c|c|c|c|c|c|}
\hline $\begin{array}{l}\text { de ciências e } \\
\text { matemática }\end{array}$ & & & $\begin{array}{l}\text { meio de um } \\
\text { jogo } \\
\text { didático em } \\
\text { um enfoque } \\
\text { CTS }\end{array}$ & & \\
\hline $\begin{array}{l}\text { Fundamentos } \\
\text { e } \\
\text { metodologias } \\
\text { para o ensino } \\
\text { de ciências e } \\
\text { matemática }\end{array}$ & $\begin{array}{l}\text { Ensino de } \\
\text { Química }\end{array}$ & Química & $\begin{array}{l}\text { A química na } \\
\text { JUNK FOOD: } \\
\text { uma proposta } \\
\text { para o ensino } \\
\text { de ligações } \\
\text { químicas por } \\
\text { meio do } \\
\text { enfoque CTS }\end{array}$ & Pós-Médio & $\begin{array}{c}\text { Guia } \\
\text { Didático }\end{array}$ \\
\hline $\begin{array}{l}\text { Fundamentos } \\
\text { e } \\
\text { metodologias } \\
\text { para o ensino } \\
\text { de ciências e } \\
\text { matemática }\end{array}$ & $\begin{array}{l}\text { Ensino de } \\
\text { Biologia }\end{array}$ & Biologia & $\begin{array}{c}\text { Meios } \\
\text { tecnológicos } \\
\text { para interagir } \\
\text { no } \\
\text { aprendizado } \\
\text { de } \\
\text { temas da } \\
\text { educação } \\
\text { ambiental }\end{array}$ & Pós-Médio & Blog \\
\hline $\begin{array}{l}\text { Fundamentos } \\
\text { e } \\
\text { metodologias } \\
\text { para o ensino } \\
\text { de ciências e } \\
\text { matemática }\end{array}$ & $\begin{array}{l}\text { Ensino de } \\
\text { Ciências }\end{array}$ & Ciências & $\begin{array}{c}\text { Objetos de } \\
\text { aprendizagem: } \\
\text { uma } \\
\text { sequência } \\
\text { didática para o } \\
\text { ensino de } \\
\text { astronomia }\end{array}$ & $\begin{array}{l}\text { Ensino } \\
\text { Fundamental }\end{array}$ & $\begin{array}{c}\text { Sequência } \\
\text { Didática }\end{array}$ \\
\hline $\begin{array}{l}\text { Fundamentos } \\
\text { e } \\
\text { metodologias } \\
\text { para o ensino } \\
\text { de ciências e } \\
\text { matemática }\end{array}$ & $\begin{array}{l}\text { Ensino de } \\
\text { Ciências }\end{array}$ & Ciências & $\begin{array}{c}\text { Sequência } \\
\text { Didática para } \\
\text { o ensino do } \\
\text { conteúdo } \\
\text { Ciclo- } \\
\text { menstrual: } \\
\text { uma } \\
\text { experiência }\end{array}$ & $\begin{array}{l}\text { Ensino } \\
\text { Fundamental }\end{array}$ & $\begin{array}{c}\text { Caderno } \\
\text { Pedagógico }\end{array}$ \\
\hline
\end{tabular}

24 DOI: Em andamento.

R. Bras. de Ensino de C\&T 


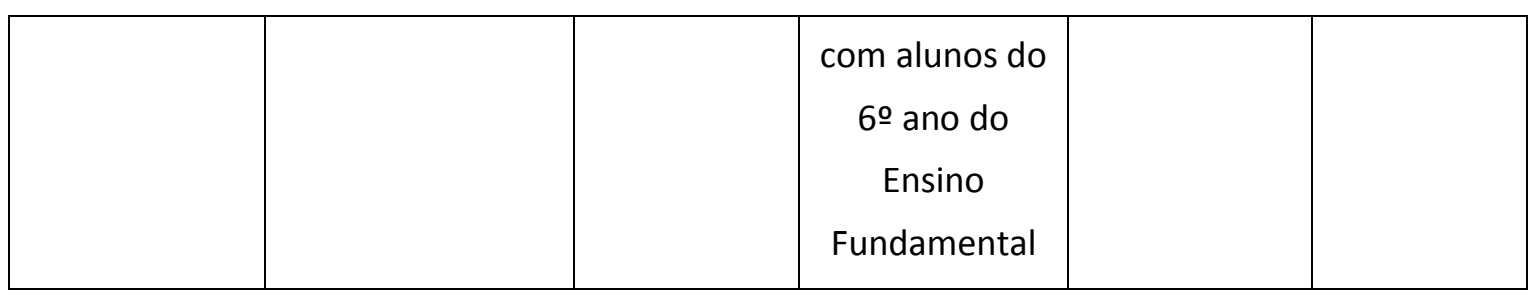

\section{Análise dos dados}

$\mathrm{Na}$ análise quantitativa dos dados, este mapeamento se faz necessário para diagnosticar a abrangência de ensino do referido programa de MP, considerando as informações das três categorias:

1. Disciplina

2. Nível de ensino

3. Produto

\section{1a Categoria- Disciplina}

Em relação a essa categoria de análise, foram identificadas dezessete (17) disciplinas de ensino de abrangência dos produtos: Química, Matemática, Física, Informática, Educação Especial, Ciências e Matemática, Ciências e Biologia, Biologia,Ciência dos Materiais, Metodologia de Ensino, Metodologia Científica, Primeiros Socorros,Saúde,Psicologia, Lazer, Ciências e Educação Física.

O gráfico 2 mostra a quantidade de produtos desenvolvidos em cada área. 


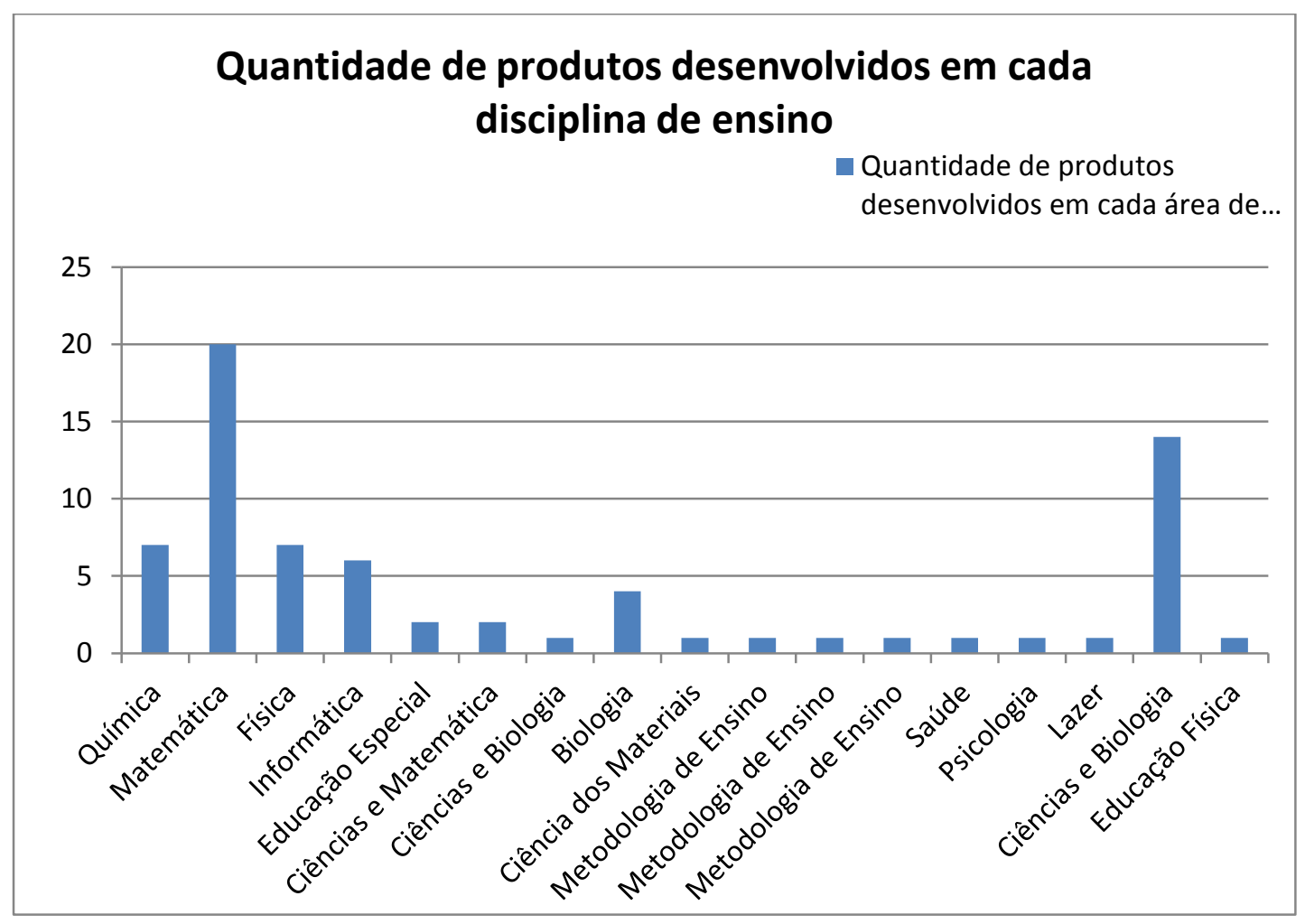

Gráfico 2- Quantidade de produtos desenvolvidos em cada

disciplina de ensino

(Fonte: Autoria própria)

Os dados acima demonstram que a maioria dos produtos desenvolvidos no (PPGECT) estão voltados para a disciplina de Matemática com um total de 20 produtos. Na disciplina de Ciências houve um número significativo de 14 produtos. As disciplinas de Física e Química apresentaram 7 produtos, sendo que Informática produziu 6, foram 4 na disciplina de Biologia, Ciências e Matemática, Educação Especial obtiveram 2 e Ciências e Biologia, Ciência dos Materiais, Metodologia de Ensino, Metodologia Científica, Primeiros Socorros, Saúde, Psicologia, Lazer e Educação Física tiveram apenas 1 produto cada disciplina.

Em seguida apresenta-se a segunda categoria de análise que considerou o nível de ensino em que se desenvolveu a pesquisa para a elaboração do produto.

\section{2a Categoria: Nível de ensino}

Das 68 dissertações analisadas, a maioria das pesquisas foi desenvolvida no Ensino Fundamental, totalizando 26 produções voltadas para este público. No Ensino Médio, foram 19, na sequência, têm-se 7 trabalhos no Pós-Médio, no Ensino Superior 9, na Educação Infantil 2, voltados para docentes 3 e no Curso Técnico apenas 1 . Esses dados podem ser visualizados no gráfico 3. 


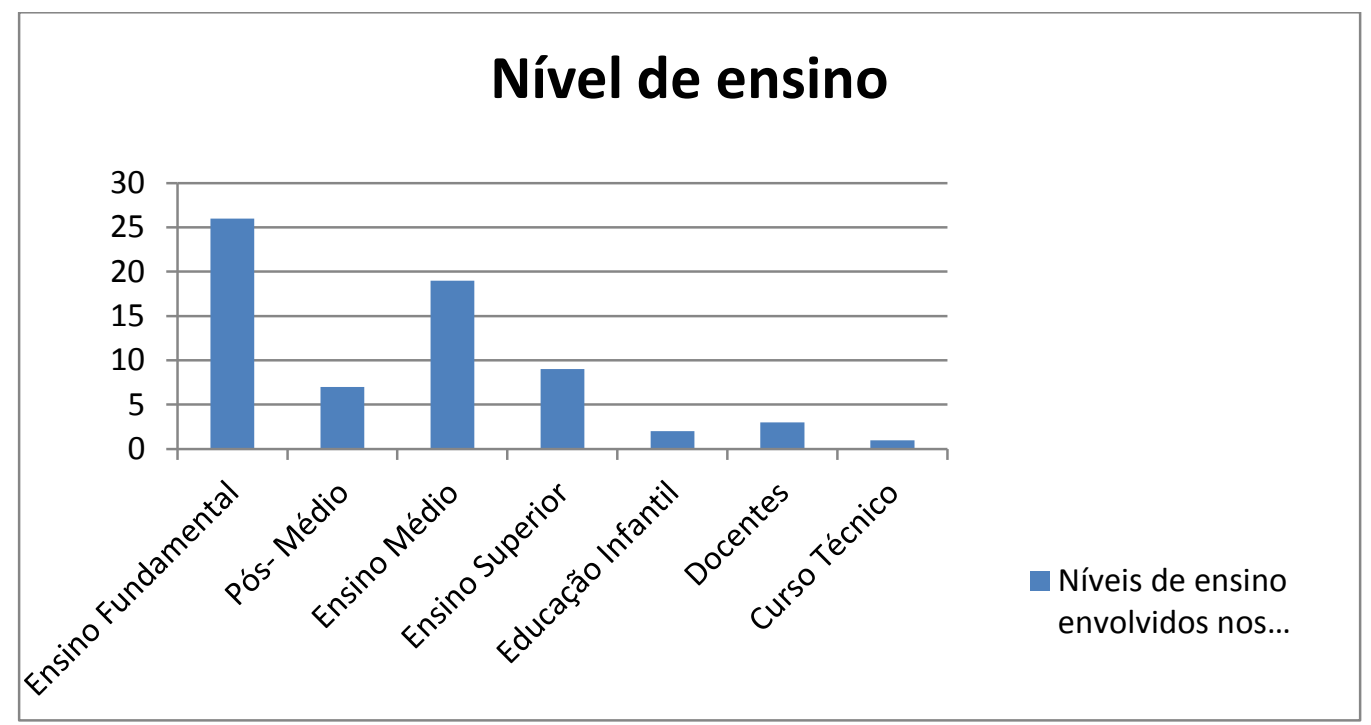

Gráfico 3. Nível de ensino

(Fonte: Autoria própria)

Considera-se que o número expressivo de produtos desenvolvido no Ensino Fundamental justifica-se pelo fato de muitos professores/pesquisadores atuarem nesse nível de ensino. A seguir apresentaremos a terceira categoria de análise.

\section{3a Categoria: Produto}

Após análise dos produtos, verificou-se que a maioria (47) dos produtos desenvolvidos se constituiu em Guias Didáticos ou de Atividades, Sequências Didáticas, Cadernos Pedagógicos ou Temáticos, Cartilhas e/ou Roteiro de Ensino. Um número menor de formatos de produtos foram desenvolvidos como: blogs, jogos, objetos de aprendizagem, vídeos, mobiliário, livros, softwares, curta metragem, biblioteca digital, DVDs, kit lúdico e protótipo. O gráfico 4 apresenta a quantidade expressiva de guias Didáticos. 


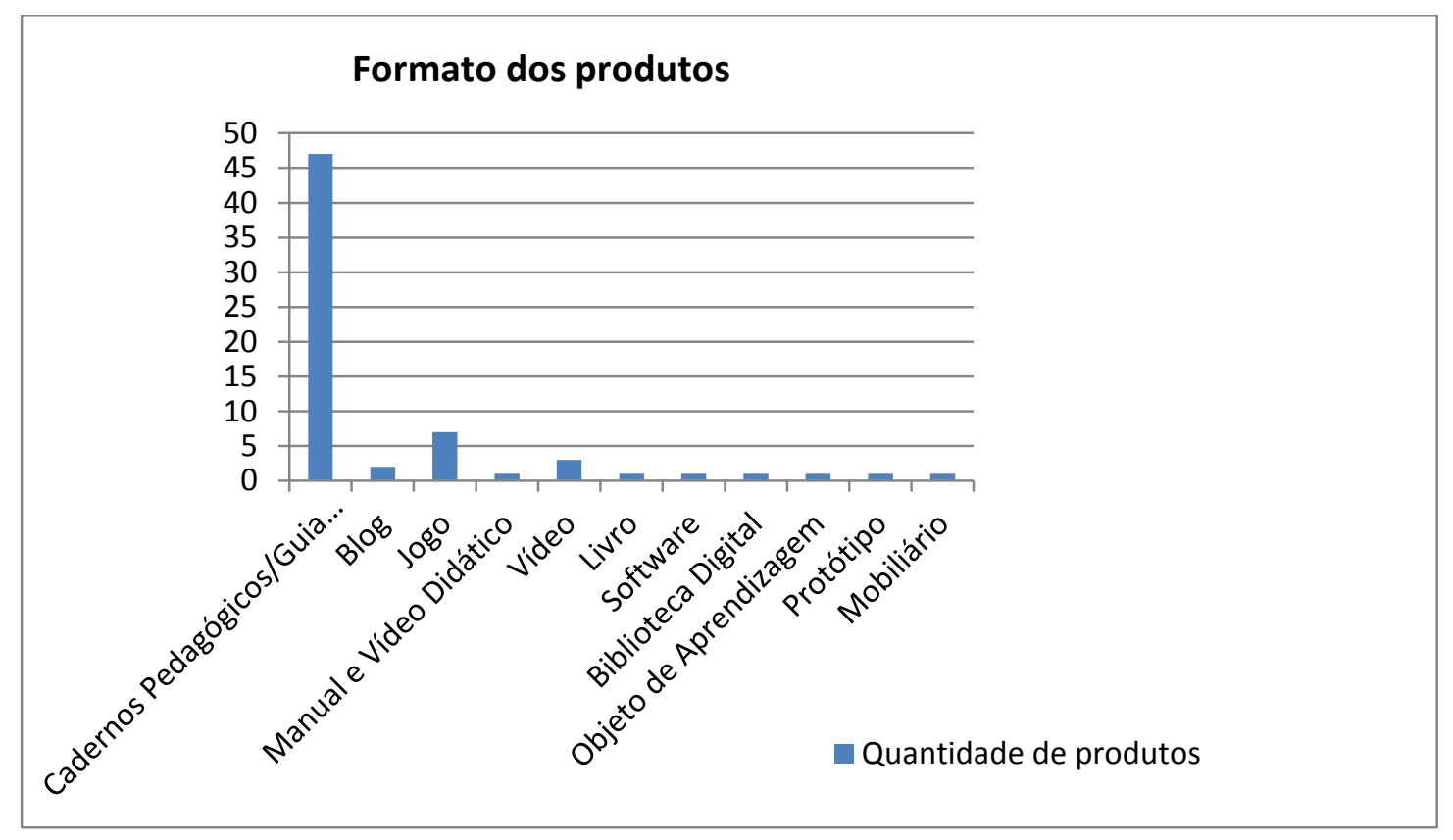

Gráfico 4- Formato dos produtos

(Fonte: Autoria própria)

Como se pode verificar, o gráfico 4 demonstra a variedade de materiais produzidos pelo programa para subsidiar o processo de ensino e aprendizagem de outros docentes. Em sua essência, um grande número de produtos se caracteriza como Guia didático sendo material de apoio para o docente da área.

\section{Considerações Finais}

Os produtos mapeados neste estudo foram gerados pelo curso de Pós-Graduação em Ensino de Ciência e Tecnologia (PPGECT) da UTFPR - Câmpus Ponta Grossa, com abrangência para a Área de Ensino de Ciências e Tecnologia.

Dos 68 materiais disponibilizados no site do programa no período de 2009 a 2013, verificou-se que a maioria teve publicação no ano de 2012, sendo que um número expressivo (47) desses produtos se apresenta em formato de guias didáticos e/ou cadernos pedagógicos, essencialmente.

Em relação ao mapeamento realizado sobre a identificação da sublinha para que os produtos estão voltados, Matemática demonstrou ter maior quantidade de produções. $\mathrm{Na}$ categoria nível de ensino, as pesquisas foram desenvolvidas em grande parte, no Ensino Fundamental. 
Com esta análise sobre o mapeamento dos produtos do MP desenvolvidos pelo PPGECT, torna-se possível gerar subsídios para novas reflexões sobre a abrangência das pesquisas no contexto de ensino sinalizando possibilidades.

\section{Referências Bibliográficas}

FERNANDES, A. Mestrado profissional - algumas reflexões. Oculum ensaios: revista de arquitetura e urbanismo - n. 4, pp. 106-109, ISSN 2318-0919, 2005.

HORTALE, V. A.; LEAL, M. C.; MOREIRA, C. O. F.; AGUiAR, A. C. Características e limites do mestrado profissional na área da Saúde: estudo com egressos da Fundação Oswaldo Cruz. Ciência \& Saúde Coletiva, 15(4):2051-2058, 2010.

LATINI, R. M.; OLIVEIRA, L. R.; ANJOS, M. B.; CARVALHO, R. H. S. B. F. Análise dos produtos de um Mestrado profissional da área de Ensino de Ciências e Matemática. Ensino, Saúde e Ambiente - v. 4 (2), p. 45-57, ISSN 1983-7011, ago. 2011.

MOREIRA, M. A., NARDI, R.O mestrado profissional na área de Ensino de Ciências e Matemática: alguns esclarecimentos. Revista Brasileira de Ensino de Ciência e Tecnologia -v.2, n.3, p. 19,set./dez.ISSN - 1982-873, 2009.

MOREIRA, H; CALEFFE, L. G. Metodologia da pesquisa para o professor pesquisador. 2 a ed. Rio de Janeiro: Lamparina, 2008.

NEGRET, Fernando. A identidade e a importância dos Mestrados Profissionais no Brasil e algumas considerações para a sua avaliação. Meta: Avaliação - Rio de Janeiro, v. 1, n. 2, p.141-149, mai./ago. 2009.

Tânia Mara Niezer (tanianiezer@terra.com.br) - Doutoranda do Programa PPGECT - Universidade Tecnológica Federal do Paraná/ Campus Ponta Grossa

Fabiane Fabri (ffabriprof@gmail.com) - Doutoranda do Programa PPGECT - Universidade Tecnológica Federal do Paraná/ Campus Ponta Grossa

Antonio Carlos Frasson (acfrasson@utfpr.edu.br) - Doutor em Educação - PPGECT - Universidade Tecnológica Federal do Paraná/ Campus Ponta Grossa

DOI: Em andamento. 
Luiz Alberto Pilatti (lapilatti@utfpr.edu.br) - Doutor em Educação Física - PPGECT - Universidade Tecnológica Federal do Paraná/ Campus Ponta Grossa 